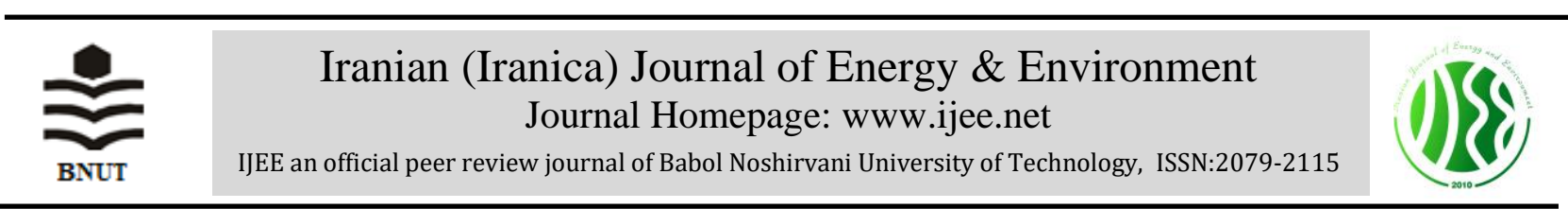

Short Communication

\title{
Anaerobic Co-digestion of Food Waste with Cow Manure
}

\author{
S. Prasad Lohani* \\ Department of Mechanical Engineering, Kathmandu University, Dhulikhel, Nepal
}

\section{PAPER INFO}

\section{Paper history:}

Received 08 November 2019

Accepted in revised form 24 February 2020

\section{Keywords:}

Biogas

Food Waste

Inoculum

Total Solid

Volatile Solid

\begin{abstract}
$\begin{array}{lllllllll}A & B & S & T & R & A & C & T\end{array}$
The composition of waste generated in urban areas of Nepal is primarily decomposable which provides scope to convert the waste into energy. In addition, organic fraction of municipal waste is a serious environmental and economic burden in Nepal. In this study, samples from food waste were taken from household of Biratnagar Metropolitan city and Kathmandu University Canteen, Dhulikhel. The samples were analyzed for physical and chemical properties and biogas production. The feed containing $6 \%$ TS were analyzed for the potential of biogas production from the canteen food waste (CFW) of Kathmandu University (KU) and household food waste (HFW) from Biratnagar in ambient and control temperature $\left(35^{\circ} \mathrm{C}\right)$ in a batch reactor. This was also conducted for food waste mixed with $30 \%$ cow manure in both the conditions. The average total solid and volatile solid for BFW were 17.7 and $93.2 \%$ of TS and CFW were 19.9 and $90.2 \%$ of TS, respectively. In every run of the experiment, the volume changes of gas were monitored. Both in the ambient and the controlled temperature, biogas production and yield were higher when $30 \%$ cow dung as inoculum was added in both samples. Moreover, the biogas production and yield of CFW was also higher than the BFW at different conditions. This shows that food wastes characteristics and biogas production potential varies depending on the source of the food waste, inoculum added and operating condition for the anaerobic digestion process.
\end{abstract}

doi: 10.5829/ijee.2020.11.01.09

\section{INTRODUCTION}

Biogas typically refers to a gas produced by the biological breakdown of organic matter such as dead plant, animal material, animal faeces, and kitchen waste in the absence of oxygen. The production of biogas from anaerobic digestion has been considered as one of the most energy-efficient and environmentally beneficial technology for bioenergy production [1].

Anaerobic digestion (AD) for treating organic waste can reduce waste volume and enrich plant nutrients in residues [2], which can then be used as fertilizer to return nutrients to the soil ecosystem $[3,4]$. The Food waste $(\mathrm{FW})$ is one of the important components of municipal solid waste mainly from household waste, food processing waste, canteen and restaurant waste. The accumulation of the FW has become a global issue [5]. It is estimated that the amount of food waste shall increase from 2.78 billion tons to 4.16 billion tons in the Asian countries by 2025 [6].

At present, in Nepal, the food wastes are being directly sent to the landfills. Population density is putting an immense pressure on municipal services to manage the ever increasing wastes. Inadequate solid waste management (SWM) in urban centers poses a serious environmental and health impact [7].
Rapid urban population growth and the continual increase in waste generation intensify the challenges. FW with high concentrations of organic matter (volatile solids/total solids [VS/TS]: 0.8-0.9), high moisture content, and good biodegradability have been regarded as the most promising anaerobic substrates $[8,9]$.

The AD process depends further on the physical properties of the substrate and the temperature. Dry and fibrous material takes longer to digest than fine-structured and wet substrate. Suitable range of TS contents of the undigested substrate is 7 to $11 \%$. A healthy digestion process shows a $\mathrm{pH}$ of 7.0 , neutral stage of substrate [10]. Similarly, the gas production also depends on the carbon to nitrogen $(\mathrm{C}: \mathrm{N})$ ratio which estimates nutrients deficiency and ammonia inhibition [11]. Optimal C:N ratio in anaerobic digesters are between 16 and 25 [12]. Optimum $\mathrm{C}: \mathrm{N}$ ratios can be ensured by mixing different feedstock materials, with high (e.g. organic solid waste) and low (e.g. sewage or animal manure) $\mathrm{C}: \mathrm{N}$ ratios to achieve an ideal C: $\mathrm{N}$ ratio level [13]. Microelements like iron, nickel, cobalt, selenium, molybdenum or tungsten are equally important for the growth and survival of the $\mathrm{AD}$ microorganisms as the macronutrients carbon, nitrogen, phosphorous, and Sulphur.

Co-digestion helps maintain the factors or necessary 
conditions required for the anaerobic digestion of organic waste [14]. Studies of co-digestion of food waste generally found that inclusion of food waste was beneficial for methane yield [15], while digestion processes with food waste as the sole substrate were often found to be unstable [9]. The beneficial effects of co-digestion are mostly related to a balanced availability of macro- and micronutrient required by the microbial community, optimal moisture content, buffer capacity and dilution of inhibitory or toxic compounds [16].

In the context of Nepal, the major sources of residential energy are fuel wood (86.5\%), animal dung (6.5\%) and agricultural residue $(3.7 \%)$, which clearly indicates a huge demand for biomass as household energy [28]. Biogas is a good example of alternative energy which can replace the hazardous fuel sources like burning of firewood. Mainly the female population and children of rural area is highly affected by the smoke produced by firewood. This has led to the increase in respiratory diseases such as ARI (acute respiratory infection) and COPD (chronic obstructive pulmonary disease [17] as well as cut down of large number of trees to sustain the demand of fuel. Huge amounts of organic wastes produced in the household kitchens have a high potential of generating methane gas to sustain themselves. This can be beneficial to families who cannot afford the LPG or electricity.

Considering the factors in which the anaerobic digestion depends, lab-scale anaerobic digesters were setup to test the biogas production from food waste from different places, the effect of temperature on the biogas production and improvement in production through co-digestion, which is the cow manure for this experiment.

\section{MATERIALS AND METHOD}

\section{Experimental setup for anaerobic digestion}

Biogas production from BFW and CFW were analyzed in laboratory for its physical and chemical properties. The total solid (TS), moisture content (MC), volatile solid (VS), total organic carbon (TOC) and total nitrogen (TN) content were determined by using standard method. Samples for food waste containing TS of $6 \%$ were arranged for experiment in ambient and controlled temperature of $35{ }^{\circ} \mathrm{C}$. The methane potential of food waste only and food waste mixed with $30 \%$ cow dung under ambient and controlled temperature conditions were assessed. A $500 \mathrm{ml}$ glass bottle was used as digester fitted with rubber cork. Level pipe was fitted into the cork and checked for leakage. The pipe was also attached to conical flask containing $\mathrm{NaOH}$ solution of 1 mole concentration, secured again with cork. Finally, another pipe collected the methane gas into an inverted measuring cylinder where the displaced water indicated the volume of gas collected. Figure 1 shows the laboratory set up of the experimentation. The volume of water that it displaced was recorded daily until the gas remained constant for more than 3 days.

The sample comprises of two different places B being of Biratnagar and $\mathrm{C}$ being of Canteen. Each sample comprises of two different feeds one with mono digestion (B1, C1) and one with $30 \%$ cow dung (B2, C2). The reactor contained 4 types of feeds with TS $6 \%$ i.e., one set for mono-digestion, and the other set for with $30 \%$ cow dung for two types of

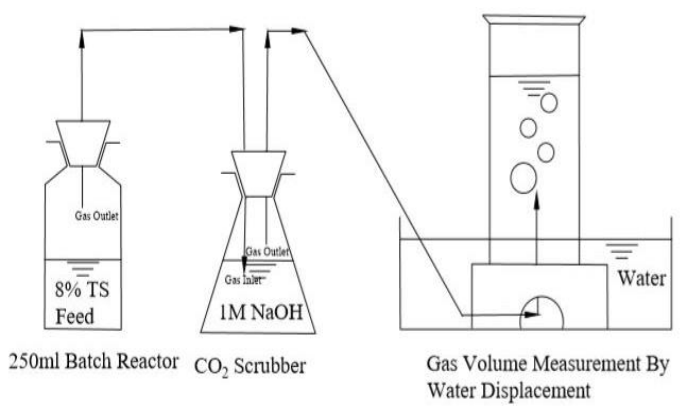

Figure 1. Schematic diagram of Laboratory experimental set up

sample. In the second setup, the same procedure was applied but this time, the temperature was controlled and maintained at $35^{\circ} \mathrm{C}$ using a water bath.

\section{RESULTS AND DISCUSSION}

\section{Physical and chemical properties of the samples}

Table 1 presents the TS and VS content of Cow dung, BFW and $\mathrm{CFW}$ as well as the $\mathrm{C}: \mathrm{N}$ ratio of these three samples. It was observed that the $\mathrm{C}: \mathrm{N}$ ratio of $\mathrm{BFW}$ samples were lower than the optimum values required for proper gas production (16-25\%). The C:N ratio of CFW were slightly higher than the BFW sample but were still inadequate than the optimum $\mathrm{C}: \mathrm{N}$ ratio. Table 1 indicates that the food habit of different places affected the characteristics of the food waste. Food waste are perhaps the most variable feedstock as the methane yield value depends not only on the sorting method, but also on the location from which the material was sourced and the time of year of collection [18].

Lower $\mathrm{C}: \mathrm{N}$ ratio may indicate ammonia accumulation. Optimum $\mathrm{C}: \mathrm{N}$ ratio is ensured by mixing high $\mathrm{C}: \mathrm{N}$ ratio substrate, in this case the cow dung, with low $\mathrm{C}: \mathrm{N}$ ratio to achieve an ideal $\mathrm{C}: \mathrm{N}$ ratio. Therefore, the food sample was mixed with cow dung for increased gas production.

It was observed that the initial $\mathrm{pH}$ of the food waste was found to be mostly acidic. Addition of cow dung as inoculum helped neutralize the $\mathrm{pH}$ of the mixed sample (food waste and cow dung), however, still the feed $\mathrm{pH}$ was between 6 to 6.2 and $\mathrm{C}: \mathrm{N}$ ratio was lower than optimum value.

\section{Biogas production}

The cumulative gas production of Biratnagar and KU canteen food waste are presented in Table 2. The maximum biogas production was observed in the canteen's food waste with $6 \%$ TS mixed with $30 \%$ of cow dung and at controlled temperature of $35^{\circ} \mathrm{C}$. This is due to the proper balance of the nutrient's availability to the anaerobes and also a proper temperature in which the anaerobic digestion was successfully carried out.

TABLE 1. Physical and chemical properties of the sample

\begin{tabular}{lcccc}
\hline Sample & TS $(\%)$ & VS $(\%$ of TS $)$ & CN Ratio & pH \\
\hline Biratnagar FW & 17.7 & 93.1 & 15.2 & 4.5 \\
\hline Cow dung & 14.1 & 87.3 & 19.1 & 6.8 \\
\hline KU canteen FW & 19.9 & 90.2 & 15.9 & 5.2 \\
\hline
\end{tabular}


TABLE 2. Cumulative biogas production

\begin{tabular}{lcc}
\hline \multirow{2}{*}{ Sample } & Ambient condition & Controlled condition $\left(\mathbf{3 7}^{\circ} \mathbf{C}\right)$ \\
\cline { 2 - 3 } & $\mathbf{6 \%}$ TS & $\mathbf{6 \%}$ TS \\
\hline B1 & 190 & 180 \\
B2 & 220 & 255 \\
C1 & 240 & 200 \\
C2 & 270 & 345 \\
\hline
\end{tabular}

Figure 2 shows that the cumulative biogas production at ambient temperature. The CFW containing 30\% cow-dung (C2) produced the highest volume of biogas $270 \mathrm{ml}$. C1 produced the second highest volume $240 \mathrm{ml}$. The BFW containing 30\% cow dung (B2) produced $220 \mathrm{ml}$ whereas the food waste only (B1) produced $190 \mathrm{ml}$ of gas. This clearly shows the difference in production of gas from food waste collected from different place. Similarly, Figure 3 shows the cumulative gas production of samples containing $6 \% \mathrm{TS}$ in controlled condition. $\mathrm{C} 2$ produced the highest amount of gas $345 \mathrm{ml}$ followed by B2 $255 \mathrm{ml}$. B1 produced the lowest amount of gas $180 \mathrm{ml}$.

\section{Biogas yield}

The biogas yields of the samples were estimated by using VS removal in the anaerobic digestion process and calculated through experimental results of methane production. Using VS, the potential of methane production per gram VS

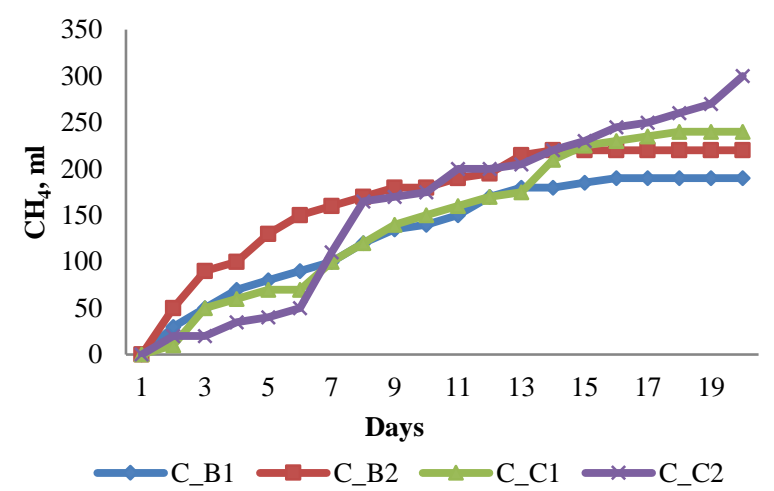

Figure 2. Methane production at ambient temperature

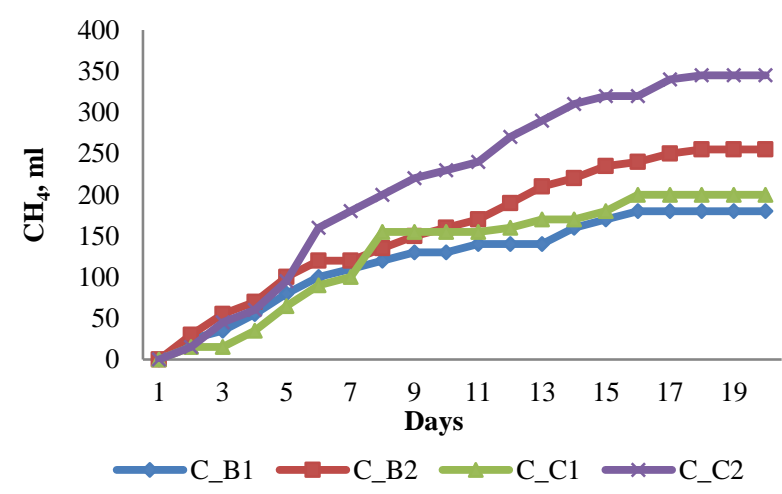

Figure 3. Methane productions at Controlled temperature removed was estimated. Table 3 shows the representative biogas yield at ambient and controlled temperatures. The comparison shows that biogas yield of $\mathrm{C} 2$ at TS $6 \%$ (ambient) is higher than that of $\mathrm{B} 2$ at TS $6 \%$ (ambient).

TABLE 3. Biogas yield

\begin{tabular}{lccc}
\hline TS & Sample & Condition & $\begin{array}{c}\text { Biogas Yield (ml CH} \\
\text { VS removed) }\end{array}$ \\
\hline $6 \%$ & Canteen (C2) & Ambient & 347 \\
$6 \%$ & Biratnagar (B2) & Ambient & 320 \\
\hline
\end{tabular}

\section{CONCLUSION}

The potential of biogas production from BFW and CFW were assessed in ambient and controlled temperature in food only and food waste mixed with $30 \%$ cow dung. From the experiment, it was concluded that the feed which had co substrate of $30 \%$ cow dung produced more amount of gas in comparison to the one without cow dung. It was also observed that the biogas production was higher in canteen food waste than that of Biratnagar food waste. This showed difference in food waste characteristics from different places differ amount of biogas production as well. Also, the food waste had acidic in nature and thus co-digestion with other substrate that can neutralize the substrate results in more gas production.

\section{ACKNOWLEDGEMENT}

The author would like to acknowledge Ms. Sanskriti Shrestha, Ms. Nistha Joshi and Mr. Komal Somai for carrying out laboratory work as undergraduate project under the author's supervision. Ms. Shristi Shakya is also acknowledged for her support in preparing the manuscripts and the university grant commission Nepal for the financial support (FRG-73/74ENGG-02).

\section{REFERENCES}

1. Weiland, P., 2010. Biogas production: current state and perspectives. Applied Microbiology and Biotechnology, 85(4), pp.849-860.

2. Odlare, M., Arthurson, V., Pell, M., Svensson, K., Nehrenheim, E. and Abubaker, J., 2011. Land application of organic waste-Effects on the soil ecosystem. Applied Energy, 88(6), pp.2210-2218.

3. Vaneeckhaute, C., Meers, E., Michels, E., Buysse, J. and Tack, F.M.G., 2013. Ecological and economic benefits of the application of bio-based mineral fertilizers in modern agriculture. Biomass and Bioenergy, 49, pp.239-248.

4. Abubaker, J., Risberg, K. and Pell, M., 2012. Biogas residues as fertilisers-Effects on wheat growth and soil microbial activities. Applied Energy, 99, pp.126-134.

5. Capson-Tojo, G., Trably, E., Rouez, M., Crest, M., Steyer, J.P., Delgenès, J.P. and Escudié, R., 2017. Dry anaerobic digestion of food waste and cardboard at different substrate loads, solid contents and codigestion proportions. Bioresource Technology, 233, pp.166-175.

6. Melikoglu, M., Lin, C. and Webb, C., 2013. Analysing global food waste problem: pinpointing the facts and estimating the energy content. Open Engineering, 3(2), pp.157-164.

7. Lohani, S.P., Chhetri, A., Adhikari, J. and Bakke, R., 2013. Sustainable 
biogas production potential from urban wastewater in Nepal. International Journal of Environmental Science and Development, 4(5), pp.595-599.

8. Ohkouchi, Y. and Inoue, Y., 2007. Impact of chemical components of organic wastes on L (+)-lactic acid production. Bioresource Technology, 98(3), pp.546-553.

9. Zhang, L., Lee, Y.W. and Jahng, D., 2011. Anaerobic co-digestion of food waste and piggery wastewater: focusing on the role of trace elements. Bioresource Technology, 102(8), pp.5048-5059.

10. Sasse, L., Kellner, C. and Kimaro, A., 1991. Improved Biogas Unit for Developing Countries. A Publication of the Deutsches Zentrum für Entwicklungstechnologien- GATE In: Deutsche Gesellschaft für Technische Zusammenarbeit (GTZ) GmbH.

11. Hartmann, H. and Ahring, B.K., 2005. Anaerobic digestion of the organic fraction of municipal solid waste: influence of co-digestion with manure. Water Research, 39(8), pp.1543-1552.

12. Deublein, D. and Steinhauser, A., 2011. Biogas from waste and renewable resources: an introduction. John Wiley \& Sons.

13. Vögeli, Y., Lohri, C.R., Gallardo, A., Diener, S. and Zurbrügg, C., 2014 Anaerobic digestion of biowaste in developing countries. Eawag, Switzerland.
14. Marañón, E., Castrillón, L., Quiroga, G., Fernández-Nava, Y., Gómez, L. and García, M.M., 2012. Co-digestion of cattle manure with food waste and sludge to increase biogas production. Waste Management, 32(10), pp.1821-1825.

15. Aichinger, P., Wadhawan, T., Kuprian, M., Higgins, M., Ebner, C., Fimml, C., Murthy, S. and Wett, B., 2015. Synergistic co-digestion of solid-organic-waste and municipal-sewage-sludge: 1 plus 1 equals more than 2 in terms of biogas production and solids reduction. Water Research, 87, pp.416-423.

16. Zamanzadeh, M., Hagen, L.H., Svensson, K., Linjordet, R. and Horn, S.J., 2017. Biogas production from food waste via co-digestion and digestion-effects on performance and microbial ecology. Scientific Reports, 7(1), pp.1-12.

17. Al-Zboon, K.K., 2017. Indoor air pollution due to household use of olive cake as a source of energy. International Journal of Environment and Waste Management, 19(3), pp.248-267.

18. Ward, A.J., Hobbs, P.J., Holliman, P.J. and Jones, D.L., 2008 Optimisation of the anaerobic digestion of agricultural resources. Bioresource Technology, 99(17), pp.7928-7940. 